\title{
Kapasitas Ovarium Ayam Petelur Aktif
}

\section{Frisandra Salanga*, Lalu Wahyudia, Edwin de Queljoea, Deidy Y. Katilia}

aJurusan Biologi, FMIPA, Unsrat, Manado

KATA K UNCI
$\begin{aligned} & \text { ayam petelur } \\ & \text { ovarium }\end{aligned}$

\begin{abstract}
A B S T R A K
Penelitian ini bertujuan untuk mengetahui kapasitas ovarium ayam petelur dengan menggunakan kontrol ayam petelur (Layer). Penelitian ini menggunakan15 ekor ayam petelur afkir yang berumur $\pm 1,5$ tahun dan 2 ekor ayam aktif dilakukan sampling secara random dan dilakukan pembedahan pada bagian rongga perut (Abdominal.) Pengamatan dilihat dari keberdaan ovarium yang ditinjau dari berat dan jumlah ovarium, folikel, dan oosit. Hasil penelitian menunjukkan bahwa keberadaan ovarium ayam afkir dengan ayam aktif tdak berbeda jauh. Berdasarkan hasil penelitian dapat disimpulkan bahwa ayam afkir (culling) menunjukkan keberadaan ovarium yaitu berat ovarium, folikel, dan oosit tidak jauh berbeda dengan ayam aktif (Layer) dalam masa produksi.
\end{abstract}

\section{K E Y W O R D S}

layer ovary
A B S T R A C T

The aim of this research was to obtain knowledge about the ovary capacity at layer using layer as the control. This research used $15 \pm 1,5$ years old culled layers. Random sampling and abdominal surgery were done on 2 active layers. The observation was done on the exsistence of ovary based on its weight and amount, follicle and oocyte. The result show's that the existence ovary of culled and active layers didn't have too many differences. It is conclude that ovary of culled layer, such as weight, follicle, oocyte, were simllar to the ovary of active layer in production period.

TERSEDIA ONLINE

10 Februari 2015

\section{Pendahuluan}

Populasi ayam ras petelur di Sulawesi Utara mencapai 940.613 ekor dengan sentra produksi terdapat di beberapa daerah seperti Minahasa, Bolaang Mongondow, Sangihe, Talaud, Kota Manado, dan Kota Bitung. Pengembangan agribisnis ayam ras petelur di Sulawesi Utara telah berkembang dengan pesat dan sudah mencukupi/memenuhi kebutuhan masyarakat sekitar di daerah tersebut (Rembet et al., 2013).

Agribisnis yang terus dikembangkan yaitu ayam petelur. Ayam petelur (layer) merupakan ayam yang ditujukan untuk produksi telur. Pemilihan unggas yang memiliki produksi yang baik dapat dilihat dari presentase jumlah produksi telur. Ayam petelur mulai berproduksi ketika mencapai umur 22 minggu (Rizal, 2006). Umur tersebut, tingkat produksi telur baru mencapai sekitar 5\% dan selanjutnya akan terus mengalami peningkatan secara cepat hingga mencapai puncak produksi yaitu sekitar 94-95\% dalam kurun waktu \pm 2 bulan (umur 25 minggu). Produksi telur diketahui telah mencapai puncaknya apabila selama 5 minggu berturut-turut persentase produksi telur sudah tidak mengalami peningkatan lagi. Sesuai dengan pola siklus bertelur, maka setelah mencapai puncak produksi, sedikit demi sedikit jumlah produksi mulai mengalami penurunan secara konstan dalam jangka waktu cukup lama (selama 52-62 minggu sejak pertama kali bertelur). Laju penurunan produksi telur secara normal berkisar antara 0,4-0,5\% per minggu. Pada saat ayam berumur 82 minggu, jumlah produksi telah berada di bawah angka 50\% dan pada kondisi demikian bisa dikatakan ayam siap diafkir (Sumarno, 2009).

Manajemen peternakan menggunakan ukuran pada umur ayam sehingga ayam yang telah tua

\footnotetext{
${ }^{*}$ Corresponding author: Jurusan Biologi FMIPA UNSRAT, Jl. Kampus Unsrat, Manado, Indonesia 95115; Email address: sandra34@yahoo.com

Published by FMIPA UNSRAT (2015)
} 
dikatakan ayam afkir. Ayam petelur afkir merupakan ayam betina petelur yang kurang repoduktif pada usia \pm 2 tahun dan siap untuk dikeluarkan dari kandang (Suprijatna dan Natawihardja, 2004). Menurut Suprijatna dan kartasudjana (2010) menyatakan bahwa untuk mempertahankan produksi telur maka ayam produktifnya menurun lagi dalam suatu kelompok ayam petelur yang sudah tua harus dikeluarkan (culling) Minimnya informasi tentang ovarium ayam petelur afkir maka perlu dilakukan penelitian tentang kapasitas ovarium ayam petelur afkir.

\section{Metode}

\subsection{Waktu dan Tempat}

Penelitian dilaksanakan pada bulan Agustus 2014 di Laboratorium Biologi Dasar UNSRAT.

\subsection{Material}

Penelitian menggunakan alat dan bahan yaitu jangka Sorong, timbangan analitik (Mini Ducin), cawan petri, kamera digital, alat bedah, Papan Bedah.

\subsection{Prosedur Penelitian}

Dilakukan sampling Ayam afkir sebanyak 15 ekor secara random. Pembedahan dilakukan bagian rongga perut (abdominal) pada setiap ekor ayam ayam. Ovarium dipisahkan dari organ reproduksi yang diambil dari ayam.Selanjutnya ovarium ayam disimpan dalam Cawan petri.

Setelah itu dilakukan pemeriksaan folikel dan oosit dengan menggunakan parameter yang diukur, yaitu :

1. Berat ovarium, folikel, dan oosit yaitu menimbang ovarium dengan menggunakan timbangan analitik dan dituliskan angka dari hasil timbangan tersebut pada setiap ekor ternak.

2. Diameter folikel yaitu folikel diukur dengan menggunakan jangka sorong dari folikel pertama hingga folikel kelima.

3. Jumlah folikel dan oosit yaitu dengan cara menghitung banyaknya jumlah oosit pada ovarium setiap ekor ayam.

\subsection{Prosedur Penelitian}

Analisis data dalam penelitian ini menggunakan Steel dan Torrie (1991) statistik kuantitatif, yaitu :

$\overline{\mathrm{X}}=\frac{X_{1}+X_{2}+X_{3}+\cdots}{n}$

Ket :

$\mathrm{n}=$ Jumlah Sampel

$\mathrm{X}_{1}=$ Parameter Penelitian

\section{Hasil dan Pembahasan}

\subsection{Ovarium Ayam}

Menunjukkan variasi berat ovarium dari 15 ekor ayam aktif pada ayam ke-10 memiliki berat ovarium dengan nilai tertinggi $35,86 \mathrm{~g}$ dan berat ovarium ayam afkir yang terendah terdapat pada ayam ke-2, yaitu 27,09 g, sedangkan berat ovarium ayam afkir tertinggi pada ayam ke-10 yaitu 53,52 g (Tabel 2). Berat ovarium yang tergolong rendah disebabkan oleh konsumsi pakan yang tidak optimal (Tabel 2). Menurut Braw-Tal et al., (2004) yang menyatakan bahwa pada saat konsumsi pakan berkurang akan mengakibatkan penurunan berat ovarium, jumlah folikel serta disfungsi dari ovarium.

Organ reproduksi betina yaitu ovarium memiliki peranan penting dalam proses reproduksi. Ovarium merupakan organ reproduksi yang berfungsi sebagai penghasil folikel. Ovarium juga merupakan tempat sintesis hormone steroid seksual, gametosis, dan perkembangan serta pemasakan kuning telur (folikel). Berat ovarium yang besar dapat menunjukkan ovarium dalam tingkat produktivitas yang tinggi (Ihsan, 2012). Hal ini yang menjadi faktor penyebab perbedaan berat ovarium yang diperoleh pada penelitian ini. Ayam afkir memiliki berat ovarium yang tinggi yaitu 40,55 g, 42,04 g, 46,09 g, dan tertinggi 53,52 g maka dapat dikatakan bahwa ayam afkir memiliki tingkat produktivitas yang tinggi. Menurut Toelihere (1985) menyatakan bahwa berat ovarium ayam dewasa yang sedang aktif bertelur atau secara normal mencapai 40-60 g. Hasil yang tidak terlalu berbeda diperoleh pada ayam petelur aktif dengan nilai ratarata $33,69 \mathrm{~g}$.

Ayam yang sedang aktif atau memasuki masa reproduksi memiliki berat ovarium tertinggi yaitu 35,31 g sedangkan berat ovarium pada ayam afkir yaitu mencapai hingga 53,52 g (Tabel 3.) maka ayam afkir juga memiliki berat ovarium yang lebih besar. Hal ini terjadi karena ayam afkir masih dapat bereproduksi dengan baik.

\subsection{Folikel Ayam}

Hasil penghitungan jumlah folikel dengan menggunakan 15 ekor ayam, pada ayam afkir memiliki jumlah folikel yaitu 4 hingga 5 folikeldengan jumlah rata-rata ayam petelur afkir sebanyak 4,6 folikel dan ayam aktif sebagai kontol atau pembanding dengan menggunakan 2 ekor ayamdengan jumlah yaitu 5 folikel dalam jumlah rata-rata yaitu 5. Menurut Yuwanta (2004) menyatakan bahwa ovarium ayam betina terdapat 5 hingga 6 folikel yang sedang berkembang, dan berwarna kuning besar (yolk).

Menunjukkan bahwa berat folikel ayam afkir berkisar antara 5,09 g dengan nilai rata-rata yaitu 1,05 gram sedangkan pada ayam aktif memiliki berat folikel terendah yaitu $8,99 \mathrm{~g}$ dengan rata-rata $27,1 \mathrm{~g}$ dan berat tertinggi yaitu $11,07 \mathrm{~g}$ dengan nilai rata-rata yaitu 24,05 . Berat folikel dipengaruhi oleh perkembangan ovarium. Ovarium merupakan tempat pembentukan folikel, maka perkembangan ovarium yang kurang baik dapat menyebabkan 
pembentukan folikel kurang sempurna (Melviyanti et al., 2013).

Pengukuran diameter folikelayam afkir dengan ukuran terbesar pada folikel pertama adalah 56 mmhingga paling kecil yaitu $\mathrm{mm}$ dengan nilai ratarata $10,02 \pm 8,14$ sedangkan ayam aktif pada folikel pertama berukuran $36 \mathrm{~mm}$ dengan nilai ratarata yaitu $10,03 \pm 1,47$. Menurut Toelihere (1985) menyatakan bahwa folikel merupakan jaringan pada ovarium yang paling cepat tumbuh,dimulai dengan garis tengah $1 \mathrm{~mm}$ dan berat $100 \mathrm{mg}$, kemudian menjadimasak dengan berat 18 hingga $20 \mathrm{~g}$ (Nalbandov, 1990).

\subsection{Oosit Ayam}

Hasil perhitungan jumlah oosit ayam afkir mencapai 1225 dengan nilai rata-rata 858,66 \pm 268,58 pada ayam petelur afkir sedangkan ayam
aktif(Layer) memiliki jumlah oosit terbanyak yaitu 1323 yang mempunyai nilai rata-rata $1093 \pm$ 325,26 (Tabel 2). Menurut Hafez (1993) menyatakan bahwa terdapat ribuan dari oosit yang memiliki ukuran $4 \mathrm{~mm}$ hingga $10 \mathrm{~mm}$ dalam diameter.

Proses pematangan oosit dan pertumbuhan embrio awal sangat dipengaruhi oleh fungsi folicle stimulating hormone (FSH) yang dihasilkan oleh hipofisa anterior. Sumantri dan Anggraeini (1999) menyatakan bahwa ovarium dengan folikel yang banyak akan memberi gambaran FSH yang tinggi. Hormon ini merupakan hormon perangsang pertumbuhan folikel dan pematangan oosit di dalam folikel.Semakin berkembang folikel maka besar dan kualitas oosit semakin meningkat (Marks et al., 2000).

Tabel 1. Ovarium ayam petelur afkir.

\begin{tabular}{ccccccc}
\hline \multirow{2}{*}{ Ayam } & Ovarium & \multicolumn{3}{c}{ Folikel } & \multicolumn{3}{c}{ Oosit } \\
\cline { 2 - 7 } & Berat $(\mathbf{g})$ & $\begin{array}{c}\text { Berat } \\
\text { (g) }\end{array}$ & Jumlah & $\begin{array}{c}\text { Ukuran } \\
(\mathbf{m m})\end{array}$ & $\begin{array}{c}\text { Berat } \\
\text { (g) }\end{array}$ & Jumlah \\
\hline A1 & 34.87 & 27.12 & 5 & 93 & 5.51 & 941 \\
A2 & 27.09 & 22.71 & 5 & 87 & 4.86 & 344 \\
A3 & 38.55 & 32.68 & 5 & 95 & 5.26 & 656 \\
A4 & 29.31 & 15.83 & 5 & 110 & 5.53 & 972 \\
A5 & 40.55 & 30.07 & 5 & 117 & 5.21 & 650 \\
A6 & 38.78 & 30.86 & 4 & 149 & 7.78 & 945 \\
A7 & 32.24 & 1.24 & 3 & 87 & 5.13 & 426 \\
A8 & 29.18 & 23.31 & 4 & 96 & 5.56 & 659 \\
A9 & 34.56 & 28.81 & 5 & 102 & 5.46 & 1085 \\
A10 & 53.52 & 47.34 & 4 & 104 & 6.23 & 1225 \\
A11 & 28.19 & 23.91 & 5 & 84 & 4.44 & 1221 \\
A12 & 32.02 & 26.36 & 4 & 84 & 4.81 & 936 \\
A13 & 46.09 & 40.07 & 5 & 122 & 4.87 & 937 \\
A14 & 42.04 & 32.51 & 5 & 112 & 9.36 & 1120 \\
A15 & 29.92 & 24.78 & 5 & 90 & 4.87 & 763 \\
\hline Total & 537,09 & 408,23 & 69 & 1532 & 84.88 & 12880 \\
\hline Rata- & & & & & & 858,66 \\
rata & 35,86 & 27.21 & 4.06 & 102.13 & 5.65 & \\
\hline & & & & & & \\
\hline
\end{tabular}

Tabel 2. Ovarium ayam petelur (Layer).

\begin{tabular}{ccccccc}
\hline \multirow{2}{*}{ Ayam } & \multicolumn{2}{c}{ Ovarium } & \multicolumn{2}{c}{ Folikel } & \multicolumn{2}{c}{ Oosit } \\
\cline { 2 - 7 } & $\begin{array}{c}\text { Berat } \\
(\mathbf{g r})\end{array}$ & $\begin{array}{c}\text { Berat } \\
(\mathbf{g r})\end{array}$ & Jumlah & $\begin{array}{c}\text { Ukuran } \\
(\mathbf{m m})\end{array}$ & $\begin{array}{c}\text { Berat } \\
(\mathbf{g r})\end{array}$ & Jumlah \\
\hline $\mathbf{A 1}$ & 35,31 & 27,01 & 5 & 113 & 6,09 & 863 \\
\hline $\mathbf{A 2}$ & 32,08 & 24,05 & 5 & 91 & 6,91 & 1323 \\
\hline Total & 67,39 & 51,15 & 10 & 204 & 13,81 & 2186 \\
\hline $\begin{array}{l}\text { Rata- } \\
\text { rata }\end{array}$ & 33,69 & 25,57 & 5 & 102 & 6,90 & 1093 \\
\hline
\end{tabular}


4. Kesimpulan

Berdasarkan hasil penelitian dapat disimpulkan bahwa ayam petelur afkir (culling) menunjukkan keberadaan ovarium yaitu berat ovarium, folikel, dan oosit tidak jauh berbeda dengan aktif (Layer) dalam masa produksi.

\section{Daftar Pustaka}

Braw-Tal, R., S. Yossefi, S. Pen, D. Schider dan A. Bar. 2004. Hormonal changes associated with aging and induced moulting of domestic hens. British Poultry Science.45 (6): 204-211.

Hafez, E.S.E. 1993. Reproduction in Farm Animals. 6 thEd. Lea and Febiger, Philadelphia. London

Ihsan, M. N. 2012. Pengaruh Umur Induk Terhadap Potensi Ketersediaan Sumber Oosit Kambing.J. Ternak Tropika. 13 (1): 33-37.

Kartasudjana, $\mathrm{R}$ dan E, Suprijatna. 2010. Manajemen Ternak Unggas. Penebar Swadaya. Jakarta

Marks, D., A.D. Marks dan C.M Smith. 2000. Biokimia Kedokteran Dasar: Sebuah Pendekatan Klinis. Penerbit EGC. Jakarta.

Melviyanti, Mita. T. 2013. Penggunaan Pakan Fungsional Mengandung Omega 3, Probiotik dan Isolat Antihistamin $\mathrm{N}_{3}$ Terhadap Bobot dan Indeks Telur Ayam Kampung. Zootek.1 (2) : 677683.

Nalbandov. A.V.1990. Fisiologi Reproduksi Pada Mamalia dan Unggas .UI Press. Jakarta.

Rembet, A. A., F. S. Oley., A. Makalew., E. K. M. Endoh. 2013. Analisis Titik Impas Usaha Ternak
Ayam Ras Petelur “ Dharma Gunawan"di Kelurahan Paniki Bawah Kecamatan Mapanget Kota Manado. Zootek.33 (1) : 11-20.

Rizal, Y. 2006. Ilmu Nutrisi Unggas. Penerbit Andalas University Press: Padang

Steel, R. G. dan Torrie, J. H. 1991.Prinsip dan Prosedur Statistika. Penerbit Gramedia. Jakarta.

Sumantri, C dan A. Anggraeini. 1999. Hubungan Jumlah Folikel Per Ovari dengan Kualitas Oosit dan Lama Hari Terbentuknya Blastosit Fertilisasi In Vitro pada Sapi Fries Holland. IImu Ternak dan Veteriner.4 (4): 142-149.

Sumarno. 2009. Manajemen Pemeliharaan Ayam Petelur di Peternakan PT. Sari Unggas Farm di Kabupaten Sragen.[Skripsi]. Fakultas Pertanian Universitas Sebelas Maret. Surakarta.

Suprijatna, E. dan D. Natawihardja.2004. Pengaruh Taraf Protein dalam Ransum pada Periode Pertumbuhan terhadap Performans Ayam Ras Petelur Tipe Medium Saat Awal Peneluran.J. Pengembangan Peternakan Tropis .29 (1): 3338.

Suprijtna, E., U, Atmarsono., dan R, Kartasudjana. 2005. IImu Dasar Ternak Unggas. Penebar Swadaya. Jakarta.

Toelihere, MR. 1985. Inseminasi Buatan Pada Ternak. Penebar Angkasa. Bandung.

Wahju, J. 1985. IImu Nutrisi Unggas. UGM- Press. Yogyakarta.

Yuwanta, T. 2004. Dasar Ternak Unggas. Penerbit Kanisius. Jakarta. 